\title{
Políticas Públicas e Competitividade da Agricultura
}

\author{
Public policy and competitiveness in agriculture
}

MARIA AUXILIADORA DE CARVALHO*

RESUMO: Nas últimas três décadas, o setor agrícola dos países menos desenvolvidos perdeu competitividade. A forte política agrícola explicaria o ganho nos países mais desenvolvidos. Sua política agrícola não mudou, mesmo quando o governo adotou uma estratégia liberal. Somente a União Europeia demonstrou ganhos de competitividade o tempo todo. Se considerarmos que, no início, apresentava a pior situação em termos de vantagem comparativa, podemos concluir que sua Política Agrícola Comum causou grande diversidade comercial e contribuiu para a redução da eficiência econômica mundial.

PALAVRAS-CHAVE: Agricultura; comércio internacional; competitividade revelada.

ABSTRACT: In the last three decades the agricultural sector of the less developed countries has lost competitiveness. The strong agricultural policy would explain the gain in the most developed countries. Their agricultural policy didn't change, even when the government adopted a liberal strategy. Only European Union has demonstrated gains in competitiveness during all of the time. If we consider that at the beginning it showed the worst situation in terms of comparative advantage, we can conclude that its Common Agricultural Policy has caused big trade diversion and contributed to the reduction of the world economic efficiency. KEYWORDS: Agriculture; international trade; revealed competitiveness.

JEL Classification: F14; F13.

\section{INTRODUÇÃO}

A percepção do papel do Estado na economia sofreu várias mudanças de direção nos dois últimos séculos. No passado, os economistas clássicos defenderam o Estado mínimo, limitado a garantir as propriedades e os contratos. Suas idéias tiveram forte influência no domínio das idéias e dos fatos. O laissez faire tornou-se o paradigma econômico durante a maior parte do século XIX e, no plano dos fatos, já no século XVIII, governantes ingleses guiavam-se pelas idéias de Adam Smith. Sua influência não se restringiu à Inglaterra, mas rapidamente atingiu os países

\footnotetext{
* Instituto de Economia Agrícola da Secretaria de Agricultura e Abastecimento do Estado de São Paulo, S.Paulo/SP, Brasil. E-mail:. macarvalho@iea.sp.gov.br.
} 
mais desenvolvidos à época, conduzindo o mundo a uma etapa em que a mão invisível era a principal agente das relações econômicas ${ }^{1}$.

No final do século XIX, no entanto, marxistas e socialistas criticaram a concentração de renda resultante do livre funcionamento do mercado. Essa crítica produziu diversas reações práticas, dentre as quais o comunismo, a mais radical, pois pretendia a eliminação do próprio mercado. Uma postura mais branda, consistiu em recomendar a intervenção do governo para neutralizar parte da concentração de renda e os efeitos do poder de monopólio. Essa foi a opção das principais nações ocidentais, como a Alemanha, que, na década de 1880, criou os primeiros sistemas de seguridade social. Essa prática se disseminou e, na década de 1920, muitos países europeus já dispunham de algum sistema de seguridade (Tanzi e Schuknecht, 1996). A Grande Depressão acelerou o processo de intervenção do Estado na economia. A defesa do Estado mínimo praticamente desapareceu. Após a Segunda Guerra o mundo todo viveu um período de entusiasmo sem precedentes quanto às possibilidades dos benefícios decorrentes da ação pública. A economia keynesiana somada à teoria dos bens públicos, externalidades e imperfeições do mercado, forneceram o referencial básico para a franca implementação de políticas econômicas ${ }^{2}$. O Estado passou a desempenhar um papel estratégico na coordenação da economia capitalista, promovendo o desenvolvimento, corrigindo distorções do mercado, criando poupança forçada e garantindo distribuição de renda mais igualitária. No mundo desenvolvido a estratégia era o Estado do bem-estar social, caracterizado por ampla proteção ao indivíduo. Nos países menos desenvolvidos delegou-se ao Estado a tarefa de viabilizar o desenvolvimento, seja pela substituição de importações, como aconteceu na América Latina, seja por políticas industriais agressivas combinadas com estratégias de exportação, como em vários países da Ásia. As elevadas taxas de crescimento desse período levaram-no a ser conhecido como anos dourados.

Nessa etapa, o paradigma econômico passou a ser o reconhecimento das falhas do mercado. A economia normativa recomendava a ação pública porque, em razão da existência de falhas, o mercado não era considerado capaz de alocar recursos com eficiência ${ }^{3}$.

\footnotetext{
${ }^{1}$ As idéias da escola clássica inglesa tiveram ampla divulgação fora da Inglaterra pelo economista francês Jean Baptiste Say e influenciaram a ação de muitos governos, em particular quanto às vantagens do livre cambismo. Ressalte-se que a aceitação dessas idéias não era irrestrita. $\mathrm{Na}$ Alemanha, por exemplo, List foi um dos principais opositores, ressaltando a necessidade de proteger a indústria nascente.

${ }^{2} \mathrm{O}$ setor agrícola concorria com uma das importantes imperfeições do mercado, qual seja, a instabilidade de preços, decorrente dos riscos e incertezas da atividade, que justificariam a intervenção do governo. Esse tema será abordado no próximo capítulo.

${ }^{3}$ Przeworski (1998) compara a evolução das controvérsias sobre o papel do Estado na economia a uma luta de boxe. Para ele, o "Estado vence o segundo round". O primeiro coube ao mercado. Trata-se da etapa em que o modelo econômico neoclássico era tido como paradigma. Nesse modelo "há mercado para tudo, hoje e sempre, todos sabem tudo e sabem a mesma coisa, não há bens públicos, não há
} 
No final da década de 1960 já se notavam sinais de ceticismo quanto à eficácia do governo, mas foi a crise dos anos 70 que reforçou os argumentos dos defensores do mercado, que ficaram conhecidos como neoliberais. Com o tempo, o neoliberalismo ganhou adeptos que passaram a atribuir ao Estado a responsabilidade de todos os problemas que o mundo viveu a partir dos anos 70, enquanto as falhas do mercado foram ignoradas. Nesse contexto o Estado mínimo passou a ser a meta, e os instrumentos para isso foram a liberalização comercial, a privatização, a desregulamentação e o ajuste fiscal (Bresser-Pereira, 1996). Stigler (1975) e Wolf (1979), por exemplo, argumentavam que, mesmo que o mercado não atue com eficiência, nada garante que o Estado possa se sair melhor. E os fatos, no seu entender, corroboravam essa asserção.

Para os neoliberais, o que leva o Estado a intervir são os interesses particulares de alguém. Logo, os motivos são os mesmos dos agentes econômicos privados. $\mathrm{O}$ problema é que, como o Estado se fortaleceu e aumentou sua participação na economia, passou a atrair crescentes interesses privados especulativos. "O comportamento do rent-seeking (busca de quase-rendas outorgadas pelo Estado) foi estimulado e sancionado pelos esquemas de proteção, promoção e regulação. O Estado se viu cada vez mais capturado pelas suas próprias criações, e nesse processo atingiu seus limites fiscais" (Frischtak, 1993, p. 15).

Dentro dessa concepção, e acreditando que os métodos burocráticos não são eficazes para neutralizar as novas modalidades de apropriação privada da res pública, sustentam que o Estado deve se restringir ao mínimo indispensável, até porque a simples possibilidade de intervenção pública seria suficiente para provocar danos à economia.

A implementação dessas práticas, no entanto, não teve o sucesso que se esperava, e a idéia de que os mercados são eficientes acabou por não ter sustentação ${ }^{4}$ Nações que acataram a maioria das recomendações ortodoxas, promovendo privatizações, abertura comercial e ajuste fiscal, continuaram sujeitas a crises e pressões especulativas, com custo social elevado ${ }^{5}$. Outras que sustentaram um Estado intervencionista, com razoável poder sobre as regras do mercado, como é o caso

externalidades, não há custo transacional nem retornos crescentes. Como, nessas condições, o mercado produz a melhor alocação de recursos possível, não há lugar para o Estado” (Przeworski, 1998, p. 41).

4 “Quando faltam alguns mercados, como inevitavelmente acontece, e a informação é endógena, como fatalmente é, já não se pode exigir que os mercados se mantenham em equilíbrio, os preços já não incluem os custos de oportunidade e podem mesmo viciar a informação, a maioria das ações individuais provoca externalidades, a informação é quase sempre assimétrica, o poder do mercado é ubíquo e abundam rents" (Przeworski, 1998, p. 43).

${ }^{5}$ O sucesso do governo Thatcher, eleito em outubro de 1979, na implementação das privatizações serviu de modelo para a difusão dessa prática no mundo, mas os resultados nem sempre foram tão favoráveis. Young (1993, p. 135), ao comparar a experiência inglesa com a de outros países europeus, pondera que “... os redamos em favor da privatização como um projeto político de validade universal podem ser seriamente postos em dúvida”. 
de Japão, Coréia e Taiwan, por algum tempo mostraram até melhor desempenho ${ }^{6}$ Além disso, a desregulamentação dos mercados de capitais, respaldada na ideologia neoliberal, aliada aos avanços tecnológicos nas indústrias de informática, telefonia e mídia, conduziu ao rápido avanço do processo de globalização financeira que, por sua vez, colocou a economia de todo o planeta vulnerável à ação dos especuladores ${ }^{7}$ A vista desses acontecimentos, a tendência passou a ser acreditar que algumas formas de intervenção são inevitáveis.

Consciente de que o Estado tem um papel positivo a desempenhar, o mundo todo tem buscado promover reformas do setor público, com o objetivo de torná-lo mais eficaz, mais eficiente e menos oneroso que no passado (Kettl, 1998). Isso porque, a despeito da interpretação teórica ou da ideologia que se adote, os fatos mostram que, até 1960, os gastos com despesas públicas em educação, saúde, e outros programas sociais, levaram a melhoras mensuráveis nos indicadores sociais. Após 1960, no entanto “... o crescimento da despesa foi socialmente menos produtivo... os dados disponíveis, ainda que limitados, sugerem que os governos pequenos não produziram indicadores sociais menos desejáveis do que os governos grandes. Além do mais, apresentaram melhores indicadores de eficiência econômica e de regulamentação" (Tanzi e Schuknecht, 1996, p. 3).

Apesar da menor eficácia, nos países desenvolvidos os gastos públicos continuam a crescer, embora a taxas menores que as observadas no passado. $\mathrm{O}$ empenho dos governos nos programas de privatizações e as tentativas de reduzir a malha de proteção social enfrentam a oposição dos grupos de interesse, tradicionais beneficiários das transferências públicas.

A agricultura constitui um exemplo claro nesse sentido. Habitual beneficiária dos subsídios e transferências dos governos dos países desenvolvidos, vem resistindo como pode a qualquer tentativa de redução da proteção pública ${ }^{8}$. O fato é que, ao longo da década de 1980, tanto nos Estados Unidos como na União Européia,

\footnotetext{
${ }^{6}$ Bresser-Pereira (1996, p. 64) observa que, embora a Coréia e Taiwan tenham adotado estratégias lideradas pelas exportações "em combinação com políticas industriais agressivas, em vez de abandonar os destinos da economia aos caprichos do mercado, não impediu que os seguidores do novo credo utilizassem esses países como exemplos das novas idéias liberais".

${ }^{7}$ Há algum tempo vem surgindo propostas no sentido de conter os excessos dos movimentos internacionais de capitais. Destaque-se o professor James Tobin, que propõe a criação de imposto sobre transações financeiras de curto prazo. Mais recentemente, após a crise asiática, iniciada em julho de 1997, a moratória da Rússia, em agosto de 1998, seguida pelo ataque especulativo sobre a moeda brasileira, até mesmo especuladores defendem a contenção da volatilidade dos capitais. É o caso do financista George Soros, que propõe a criação de uma agência internacional de seguros que estabeleça limites de crédito protegido aos países interessados.

${ }^{8}$ Um exemplo expressivo dessa atitude contrária à retração do apoio público é a manifestação dos agricultores com seus tratores nas ruas de Paris. Destaque-se que os Estados Unidos, desde o final dos anos 1970, em razão do acúmulo de estoques, vinham tentando reduzir o apoio ao setor, mas sem muito sucesso. Na União Européia, a primeira tentativa de reforma da Política Agrícola Comum aconteceu em 1969, mas fracassou. Na década de 1980 introduziu alterações visando reduzir o protecionismo, mas, adespeito desses esforços, os gastos públicos continuaram a crescer (Carvalho e Silva, 1994).
} 
principais exportadores mundiais de produtos agrícolas, a tendência de aumento das despesas orçamentárias com o setor é nítida (Bocker, 1994 e Carvalho e Silva, 1994). O interessante é que esse foi exatamente o período de maiores esforços no sentido de reduzir o papel do Estado de acordo com o credo neoliberal'.

Ao que parece, a agricultura dos países desenvolvidos, a despeito de inúmeros questionamentos ${ }^{10}$, pôde continuar sua trajetória expansionista, contando com recursos públicos para isso. Pelo menos na União Européia (UE) a agricultura foi capaz de gerar excedentes que, exportados a preços subsidiados, possibilitou a expansão de sua participação no mercado internacional de commodities agrícolas ${ }^{11}$

Enquanto a agricultura dos países desenvolvidos contava com volumes crescentes de recursos públicos, nas economias mais pobres a crise econômica desarticulou as políticas setoriais implementadas até então, forçando-as a ajustamentos com elevados custos sociais. Na década de 1980 isso aconteceu de forma mais dramática nas nações endividadas, como o Brasil, que passaram a enfrentar forte estrangulamento externo, grandes dificuldades para estabilizar a economia e grave crise fiscal do Estado ${ }^{12}$.

No Brasil essas dificuldades vêm sendo contornadas pelo populismo econômi$\mathrm{co}^{13}$. Diante de pressões políticas dos diferentes grupos de interesse, e na impossibilidade de atender todos, o governo acaba por conduzir a economia alternando políticas expansionistas para atender determinados pleitos, logo seguidas por retração, em decorrência das restrições orçamentárias. A agricultura é um bom exemplo dessa prática. Desde meados da década de 1960 o governo brasileiro vinha sustentando um amplo programa de modernização da agricultura, calcado no crédito rural subsidiado e no intenso uso de insumos. Esse programa começou a ser abandonado no início da década de 1980, em decorrência dos constrangimentos por que passou o Estado brasileiro. Passamos então a viver uma etapa em que se

\footnotetext{
${ }^{9}$ Abreu e Loyo (1994, p. 76), ao tentar explicar a lógica da sustentação de políticas agrícolas, com custos elevados para os consumidores e contribuintes, ponderam que “.... talvez o melhor que se possa alegar seja mesmo o tamanho do setor agrícola, e, em especial, seu tamanho eleitoral, magnificado em relação à sua participação no emprego pela estrutura distrital do voto nas principais economias desenvolvidas... a proteção agrícola é mais palatável ao eleitorado em geral por não ter a impopular conotação de defesa dos grandes interesses econômicos".

${ }^{10}$ Que serão discutidos no próximo tópico.

${ }^{11} \mathrm{Na}$ realidade, foi a agricultura que possibilitou à União Européia sustentar sua participação nas receitas de exportação em torno de $50 \%$, uma vez que perdeu mercado no comércio de outros produtos. Esse tema é discutido no tópico Metodologia.

${ }^{12} \mathrm{O}$ conceito de crise fiscal do Estado foi introduzido por O’Connor (1973) para caracterizar a situação de dificuldade do Estado em lidar com as crescentes demandas dos diferentes setores econômicos e grupos sociais.

${ }^{13}$ A prática é chamada populismo econômico para distinguir da idéia de populismo disseminada na América Latina, conceito vinculado aos líderes políticos que estabelecem relação direta com o povo sem a intermediação de partidos políticos. O conceito também está relacionado aos pactos políticos entre industriais, trabalhadores e classe média burocrática para promover a substituição de importações (BresserPereira, 1998, p. 169).
} 
alternam maior e menor disponibilidade de recursos, com ênfase nos objetivos de curto prazo e nítida tendência de redução de apoio ao setor ${ }^{14}$.

A retração do apoio público se refletiu na capacidade de competição de nossa agricultura no mercado internacional, em particular a partir de 1978 ( Carvalho, 1996). Com base nesse resultado, esse trabalho procura testar a hipótese de que essa tendência não se limitou ao Brasil, mas caracterizou o comércio agropecuário da maioria dos países menos desenvolvidos, que também negligenciaram suas agriculturas, enquanto os produtos agropecuários das economias mais industrializadas, amplamente apoiados institucionalmente, ganharam competitividade no mercado internacional.

Para desenvolver esse argumento, no próximo item é apresentada uma discussão mais detalhada das políticas públicas voltadas para a agricultura. Em seguida são apresentados os conceitos de vantagem relativa na exportação e competitividade revelada, usados para avaliar a evolução da competitividade da agricultura, brasileira e dos principais países. No quarto item são apresentados os resultados. $\mathrm{O}$ trabalho se encerra com algumas considerações finais.

\section{POLÍTICAS PÚBLICAS E AGRICULTURA}

Considera-se falha do mercado o conjunto de condições sob as quais uma economia de mercado é incapaz de distribuir recursos de maneira eficiente. Normalmente são identificadas as seguintes: (a) existência de bens públicos, cujo consumo por um usuário não reduz o estoque disponível para outros; (b) mercados imperfeitos que podem levar à formação de monopólios ou atividades que exijam grande escala na produção; (c) externalidades, que podem ser positivas ou negativas; e (d) informação imperfeita.

A ocorrência dessas falhas é o argumento básico para a função alocativa do governo, situação em que o poder público intervém diretamente no processo produtivo, ofertando o bem em questão ou direcionando a iniciativa privada através de estímulos ou penalidades.

O setor agrícola concorre com uma das importantes falhas do mercado. Isso porque, onde há riscos e incertezas, as informações disponíveis para a tomada de decisão são imperfeitas, e os agentes econômicos podem cometer erros na alocação de rec ursos ${ }^{15}$. Assim, na ausência de intervenção pública, o setor poderá estar

\footnotetext{
${ }^{14}$ No Brasil, por algum tempo, a política de preços mínimos representou importante instrumento de apoio ao setor, em substituição à política de crédito subsidiado. A partir do final dos anos 80 ela também perdeu expressão (Carvalho, 1994).

${ }^{15}$ Sonka e Patrick (1984) identificaram cinco fontes de risco para os agricultores: (a) risco de produção ou técnico, associado a problemas climáticos, pragas e doenças; (b) risco de preço; (c) risco tecnológico, existente quando da realização de investimentos; (d) risco legal ou social, como as mudanças nas regras estabelecidas pelo governo para estabilizar preços, compras, ou condições de crédito etc.; e (e) fontes humanas de risco, como greves de trabalhadores no período da colheita.
} 
permanentemente em crise, ora de excesso de produção, ora de insuficiência de oferta, problema que compromete a estabilidade de todo o sistema econômico.

Antes mesmo de se ter qualquer referencial teórico para a análise desse problema, a prática do protecionismo na agricultura era amplamente difundida ${ }^{16}$. No século XX, as dificuldades enfrentadas pelo setor levaram os governos a intervir, e o brasileiro foi um dos que se destacou nessa prática. A literatura registra o Convénio de Taubaté, de 1906, como um episódio marcante do protecionismo agrícola que mudou a história econômica do Brasil ${ }^{17}$.

Delgado (1978) associa as primeiras medidas de intervenção pública sobre a agricultura, com o propósito de estabilizar preços, às conseqüências da crise de 1929. Em 1931 o governo francês iniciou intervenção no mercado de vinho e em seguida estendeu-a ao trigo. A Inglaterra e os Estados Unidos iniciaram em $1933^{18}$.

Enquanto na fase inicial o poder público buscou, simplesmente, responder às pressões decorrentes das crises enfrentadas pela agricultura, com o tempo, e a evolução do papel do Estado na economia, desenvolveu-se uma postura deliberada visando estabilizar os preços e garantir a renda dos agricultores. Johnson (1947) foi quem consolidou a abordagem teórica que justifica a ação pública sobre a agricultura.

A elevada instabilidade de preços é o centro da discussão. Em seu entender, os produtores não têm a dimensão exata do problema. Quando o preço de determinado produto se eleva, os agricultores, acreditando que se manterá elevado, deslocam recursos para aumentar sua produção mas, na época da colheita, o preço cai, tendo havido, portanto, um emprego excessivo de recursos. A implicação disso é que o livre mercado não é eficiente para fornecer e disseminar a quantidade e a qualidade necessárias de informação para orientar os agricultores.

Reconhecendo que, por causa desse tipo de incerteza, importantes pressupostos referentes ao bem-estar não são cumpridos, Johnson (194 7) conclui que algum

\footnotetext{
${ }^{16}$ Ressalte-se que o protecionismo agrícola está arraigado na tradição européia há muito tempo. As obras dos clássicos são repletas de menções a essa prática no período mercantilista. Posteriormente, no final do século XIX, época reconhecida como de ampla aceitação do ideário liberal, a agricultura européia viveu um período de recrudescimento protecionista.

${ }^{17}$ No final do século XIX houve grande expansão da cultura cafeeira que levou à crise de superprodução nos anos iniciais do século seguinte. Como o Brasil detinha 3/4 da produção mundial, ficou em situação favorável para controlar a oferta e evitar a queda do preço do produto. Pelo convênio celebrado em Taubaté, em fevereiro de 1906, foram definidas as bases da chamada política de valorização do produto, que consistia no seguinte: os excedentes de produção seriam adquiridos pelo governo com recursos obtidos no exterior; esses empréstimos seriam pagos por um imposto sobre o café exportado; e os governos dos estados produtores deveriam desencorajar a expansão da produção. Como esse último objetivo não foi atingido de imediato, porque a política de valorização sustentava a rentabilidade da cafeicultura, acabou provocando acúmulo de excedentes invendáveis até que o governo decidiu pela sua destruição. A queima dos estoques levou ao deslocamento dos recursos da cultura do café para a atividade industrial (Furtado, 1969).

${ }^{18}$ É desse ano o Agricultura/ Adjustment Act norte-americano, política cujo objetivo era reduzir a área de certas culturas e garantir preços mínimos e que, com algumas adaptações, existe até hoje.
} 
tipo de ação positiva é necessário para conduzir à melhor alocação. Sua proposta é a adoção de um sistema de preços antecipados (forward-prices system), cujo propósito é transferir a incerteza enfrentada pelo produtor individual para a economia como um todo. A idéia é dar condições ao setor agrícola para que cresça em harmonia com os demais, uma vez que, por suas peculiaridades, está sujeito a maior grau de incerteza.

Destaque-se que a preocupação de garantir o bom funcionamento de todo o sistema econômico sempre esteve no centro da discussão sobre a agricultura. O ponto de partida talvez seja o tableau economique de Quesnay, passando pelos clássicos, neoclássicos, estruturalistas etc. É esse também o enfoque de alguns dos princípios propostos pela FAO (Organização das Nações Unidas para Agricultura e Alimentação) a serem perseguidos pela política agrícola de todos os países.

O seguinte princípio é explícito a esse respeito: "um crescimento equilibrado da economia como um todo, sem excessivos pagamentos de transferência da agricultura a outros setores da economia (como na maioria dos países subdesenvolvidos), ou de outros setores da economia para a agricultura (como em grande número de países desenvolvidos)" (FAO, 1961).

Observe-se também que, já em 1961, existia a preocupação da FAO com as diferenças entre países ricos e pobres quanto à forma de condução da política agrícola. Os países desenvolvidos, em alguns casos pressionados por situação desfavorável, mas respaldados nas teorias que justificam o apoio do Estado à agricultura, desenvolveram fortes esquemas de proteção ao setor. Nos Estados Unidos, essa prática se consolidou desde o New Deal, no início da década de 1930, e tem sido apontada como a causa central da pujança de sua agricultura e do avanço tecnológico no meio rural.

Também na Europa a intervenção pública é causa do avanço tecnológico na agricultura. Esse continente, historicamente importador de alimentos, enfrentou duas situações dramáticas de desabastecimento após as grandes guerras do século $\mathrm{XX}$. Nessas ocasiões, a principal tarefa dos governos era gerir a escassez, mas a vontade política de evitar a repetição dessas dificuldades e atingir a auto-suficiência levou ao aumento da intervenção pública na agricultura.

A percepção de que políticas independentes poderiam causar distorções no comércio levou à criação da Política Agrícola Comum (PAC), cujos objetivos e principais características foram definidos no Tratado de Roma, em 1957. O resultado em termos de aumento da produção foi tão nítido que menos de vinte anos depois passaram a exportadores líquidos de produtos agrícolas (Carvalho e Silva, 1994) $)^{19}$.

Nos países mais atrasados, após a Segunda Guerra a preocupação era outra. As teorias sobre as razões do subdesenvolvimento ganharam expressão e, para muitos autores, a agricultura passou a ser vista como um setor estratégico. Lewis

\footnotetext{
19 Thorstensen (1993) aponta a PAC como um dos pilares básicos da União Européia e ressalta que a Política Comercial Comum do bloco está subordinada ao seu desempenho.
} 
(1954), Fei e Ranis (1964) e Jorgenson (1961) foram importantes autores que atribuíram à agricultura papel relevante no processo de desenvolvimento devido à sua contribuição em termos de liberação de mão-de-obra, como provedora de poupança para a acumulação ou devido à oferta de alimentos a baixo preço.

Nessa etapa, em que desenvolvimento era sinónimo de industrialização, muitos países, inclusive o Brasil, desenvolveram forte intervenção na economia, implementando o programa de substituição de importações que implicou a discriminação contra a agricultura.

Muitos autores concluem pelo viés urbano dessa fase, e a conclusão geral é que, para propiciar o desenvolvimento industrial, a agricultura foi taxada em muitos países. A taxação é interpretada num sentido amplo, de forma a incluir políticas de preços, sobrevalorização cambial e outras medidas protecionistas ${ }^{20}$.

Assim, enquanto o mundo desenvolvido articulava uma infinidade de mecanismos de apoio à agricultura, entre os mais pobres a estratégia era extrair excedentes do setor para viabilizar a consolidação da indústria.

Entre meados da década de 1960 e início da seguinte ocorreu uma mudança na estratégia de desenvolvimento. Essa nova estratégia foi influenciada por autores como Jonhston e Mellor (1961), responsáveis pela identificação das cinco funções da agricultura para o desenvolvimento econômico, quais sejam: produzir alimentos a baixo preço para as cidades, liberar mão-de-obra para a indústria, fornecer recursos para a formação de capital, abrir mercado consumidor para produtos industriais e produzir excedentes para a exportação, aumentando assim a capacidade de importação.

Uma das condições para o cumprimento satisfatório dessas funções era o aumento da produtividade e redução dos custos através da adoção de moderna tecnologia. Esse enfoque do problema provocou mudanças na condução das políticas agrícolas de muitos países cujos governos estavam dispostos a induzir o desenvolvimento. Os países asiáticos como Filipinas, Índia, Paquistão, Coréia do Sul, Malásia, entre outros, constituem importantes exemplos de intervenção pública com esse propósito. Após grave crise de alimentação entre 1965 e 1966, os governos optaram por alocar recursos orçamentários na atividade. O programa incluía viabilizar a importação de sementes melhoradas, matérias primas e fertilizantes, sempre que necessário, para induzir o avanço tecnológico no setor. $\mathrm{O}$ rápido incremento da produção e produtividade, em especial de arroz e trigo, despertou uma onda de otimismo em todo o mundo subdesenvolvido que resultou em denominar o processo de revolução verde (Brown, 1983).

O Brasil também aderiu a essa estratégia. A partir de meados dos anos 60,

\footnotetext{
${ }^{20}$ Para o Brasil, esse enfoque foi desenvolvido por Veiga (1974), que constatou o ônus para o setor como decorrente do baixo custo da moeda estrangeira, política adotada com o fito de facilitar a importação de matérias-primas e de bens de capital para viabilizar a indústria. A Índia viveu problema semelhante. "Acreditando que o potencial da agricultura e das exportaçôes era limitado, os governos da Índia decidiram tributá-la, distorcendo contra ela as relações de troca e enfatizando a substituição de importações” (Banco Mundial, 1997, p. 24).
} 
promoveu um ambicioso programa de modernização da agricultura que, segundo Mendonça de Barros (1982), baseou-se em quatro pontos principais: maior abertura ao comércio internacional, forte expansão dos programas de crédito rural subsidiado, aumento dos gastos com extensão rural e especial tratamento do setor de insumos (tratores, fertilizantes, inseticidas e herbicidas).

Dentre esses pontos, merece destaque o crédito rural como o grande agente viabilizador das transformações que se seguiram. Na suposição de que a modernização da agricultura exigiria elevação de gastos com insumos produzidos fora da propriedade, elevando a necessidade de crédito, dificilmente atendida pelos canais financeiros normais, o governo assumiu a responsabilidade de financiar o processo, implementando, em 1965, o chamado Sistema Nacional de Crédito Rural.

Os efeitos da estratégia de política adotada se fizeram sentir das mais variadas formas. Produziram-se transformações profundas no setor agrícola no que diz respeito ao emprego, à tecnologia, à composição da produção, ao uso e posse da terra e às relações com outros setores da economia ${ }^{21}$.

Os questionamentos qul'Into à conveniência dessas transformações logo começaram a aparecer. As críticas, em sua maioria, recaíam sobre a eficácia do subsídio ao crédito rural, ressaltando seu efeito concentrador de terra, os desvios de recursos para outras finalidades etc. ${ }^{22}$

No final da década de 70, a estratégia de modernização da agricultura começou a ser abandonada, em parte em razão dos problemas apontados, mas, mais particularmente em decorrência dos constrangimentos a que o país se submeteu. Lembrar que a partir de 1973, em menos de dez anos, somaram-se a crise do petróleo, a dos juros e a da dívida externa, elementos que levaram à crise fiscal do Estado brasileiro que, por sua vez, inviabilizou a continuidade de qualquer estratégia desenvolvimentista.

Enquanto países pobres, como Brasil, México, Índia, Filipinas etc. realizavam enormes esforços na crença que seu desenvolvimento dependia da modernização da agricultura, nações mais avançadas já contribuíam para reduzir suas possibilidades de sucesso. A questão é que a estratégia dos menos desenvolvidos passava por gerar excedentes agrícolas exportáveis, objetivo que conflitava com política protecionista das nações industrializadas, potenciais mercados para sua produção. Brown (1983), escrevendo em 1969, mencionava a necessidade de pressionar a abertura à importação no Japão e nos países da Comunidade Econômica Européia, “... onde a produção de cereais é freqüentemente subsidiada a preços duas vezes mais altos que os preços do mercado".

21 Castro (1979) observou que nessa etapa o crédito rural era absorvido predominantemente pelos médios e grandes estabelecimentos rurais e que teve papel fundamental na viabilização do setor industrial, garantindo demanda por seus produtos.

22 Também na Ásia a política foi sujeita a críticas. Johnson (1975, p. 273) observou que “... após seis ou sete anos, uma colheita desastrosa no sul da Ásia causou desilusões na maioria dos técnicos que antes mostravam-se tão otimistas". 
Os maiores entraves procedem exatamente do poder público das nações desenvolvidas. A partir do momento em que ele passou a tomar a si a tarefa de conduzir os destinos da agricultura, os países menos desenvolvidos passaram a perder competitividade nesse mercado.

As políticas públicas voltadas para a agricultura do mundo desenvolvido vêm desde os anos 30 e atacam em diversas frentes, com destaque para os gastos com pesquisa, passando pela sustentação de preços e renda dos agricultores, barreiras à importação, subsídios à exportação etc., fatores que induzem ganhos de produtividade e maior espaço no mercado.

Johnson (1975, p. 274) dá ênfase à importância dos gastos públicos em pesquisa quando afirma: "Pode surpreendê-los saber que as produtividades de cereais nos países industrializados - principalmente na Europa e América do Norte - e nos países em desenvolvimento foram idênticas em 1935/39. No entanto, a produtividade atual nos países industriais é pelo menos $50 \%$ maior do que nos países em desenvolvimento".

O problema fundamental é a enorme disparidade nos volumes de recursos transferidos para o setor agrícola entre países pobres e ricos ${ }^{23}$. O interessante é que mesmo quando as nações industrializadas passaram a reorientar o papel do Estado na economia para a abordagem neoliberal, praticamente nada se fez para reduzir a intervenção sobre a agricultura, e não foi por falta de estudos que ressaltassem as perdas de eficiência resultantes do pro tecionismo ${ }^{24}$.

Pelo contrário, exatamente no período em que a Inglaterra vivia sob o governo Thatcher e muitos outros países procuraram imitar seu modelo de gestão pública, o mundo desenvolvido passou por uma etapa de acirramento da proteção à agricultura. Coutinho (1994), por exemplo, menciona que a participação da Comunidade Européia no mercado agrícola mundial foi incrementada consideravelmente após 1983.

Os Estados Unidos, que viviam sob a gestão conservadora de Reagan, em maio de 1985 “... criam o Export Enhancement Program (EEP) como forma de retaliação aos subsídios às exportações da CEE, para tentar recuperar mercados perdidos e forçar a CEE a negociar a questão agrícola"(Fagundes, 1994, p. 18 $)^{25}$.

As negociações tiveram início em 1986, na Rodada Uruguai do GATT. O processo foi longo e complicado e, em várias oportunidades, chegou a ameaçar a própria continuidade das negociações. Para muitos analistas, essa Rodada se caracterizou pela disputa entre os Estados Unidos ${ }^{26}$, que tinham por objetivo a elimi-

\footnotetext{
${ }^{23}$ Nos países pobres, freqüentemente as transferências são oriundas da agricultura para o restante da economia.

${ }^{24}$ Ver, por exemplo, Sanderson (1990), Stoeckel et ai. (1989) e Tyers e Anderson (1988).

${ }^{25}$ A disputa entre esses dois gigantes provocou perdas consideráveis para os países em desenvolvimento, que perderam fatias de mercado, continuando o declínio iniciado desde meados dos anos 60 (Coutinho, 1994).

${ }^{26}$ Apoiados pelo grupo de Cairns, composto de Argentina, Austrália, Brasil, Canadá, Chile, Colômbia, Fiji, Hungria, Indonésia, Malásia, Nova Zelândia, Filipinas, Tailândia e Uruguai.
} 
nação dos subsídios ao comércio de produtos agrícolas, e a União Européia, que buscava defender sua Política Agrícola Comum.

Ao final, ambos chegaram a um acordo de redução paulatina do apoio à agricultura, que acabou por ser ratificado pelos demais membros ${ }^{27}$. Ressalte-se que os avanços em termos de liberalização comercial foram relativamente tímidos. $\mathrm{O}$ curioso é que esta é uma das principais recomendações do pensamento neoliberal, que tem o Estado mínimo como meta de política econômica.

\section{METODOLOGIA}

O conceito de competitividade empregado neste trabalho diz respeito às variações da participação do país, ou grupo de países, no comércio internacional ${ }^{28}$. Balassa (1965) denominou vantagem comparativa revelada à medida que possibilita avaliar a competitividade a partir das informações passadas do comércio. Esse método foi empregado sobre os dados do comércio mundial de produtos agrícolas, incluindo os aperfeiçoamentos propostos por Vollrath (1989) e consistem nos seguintes indicadores:

\section{Vantagem Relativa na Exportação}

Vantagem relativa na exportação (VRE) é um indicador útil para analisar o desempenho de um país (ou grupo deles) nas exportações de determinado produto. É calculado através da seguinte expressão:

$$
V R E_{k i}=\ln \left[\frac{X_{k i} / X_{k r}}{X_{m i} / X_{m r}}\right]
$$

onde $X$ corresponde à exportação, o subscrito $k$ refere-se ao produto e $i$, ao país. $\mathrm{O}$ subscrito $m$ refere-se ao agregado dos produtos, excluindo $k$, e $r$ ao agregado de todos os países, excluindo $i$.

Se $V R E_{k i}=0$ significa que a participação das exportações do produto $k$ no total das exportações do país $i$ é idêntica à observada na média dos demais países, caracterizando uma situação neutra, ou seja, o país não revela vantagem nem desvantagem no comércio do produto $k$. Se $V R E_{k i}>0$, o país $i$ revela vantagem na exportação de $k$ e, naturalmente, se $V R E_{k i}<0$, desvantagem.

\footnotetext{
${ }^{27}$ Histórico sobre as negociações agrícolas no GATT, em particular sobre a Rodada Uruguai, podem ser encontrados em Fagundes (1994) e Carvalho e Silva (1994).

${ }^{28}$ Fajnzylber (1988) dá uma interpretação mais abrangente ao conceito. Define competitividade, sob uma perspectiva de médio e longo prazo, como a capacidade de um país sustentar e expandir sua participação no mercado internacional enquanto eleva, simultaneamente, o nível de vida da população. A partir dessa definição, a maneira de atingir melhoria de competitividade é o progresso técnico.
} 


\section{Competitividade Revelada}

Competitividade revelada (CR) é um indicador mais abrangente porque engloba todo o comércio, e não somente as exportações. Também foi proposto por VOLLRATH (1989) e constitui uma medida útil para análises agregadas quando produtos do setor são exportados e importados pelo país. Os resultados são obtidos pelo emprego da seguinte expressão algébrica:

$$
C R_{k i}=\ln \left[\frac{X_{k i} / X_{k r}}{X_{m i} / X_{m r}} / \frac{M_{k i} / M_{k r}}{M_{m i} / M_{m r}}\right]
$$

onde $M$ indica o valor das importações.

A interpretação do resultado do cálculo de CR segue a mesma lógica de VRE, ou seja, se $C R_{k i}>0$ o país revela vantagem comparativa no comércio de $k$ e, naturalmente, se $C R_{k i}<0$, desvantagem.

\section{DISCUSSÃO DOS RESULTADOS}

A hipótese básica desta pesquisa é que o desempenho dos países em termos de competitividade da agropecuária foi condicionado pela intervenção do Estado. Procuramos testá-la de maneira indireta, ou seja, identificando os que ganharam ou perderam competitividade. Este é o propósito deste capítulo. Com base nesse diagnóstico tecemos considerações sobre as políticas públicas voltadas para a agricultura, que pode justificar o sucesso ou o fracasso no mercado internacional.

Inicialmente constatamos que, no período 1961-95, as exportações mundiais evoluíram, em termos nominais, à taxa de 12,0\% a.a. Se dividimos o mundo em dois grupos, desenvolvidos e em desenvolvimento, observamos nos primeiros, taxa de crescimento praticamente igual à média mundial (11,8\% a.a.). Os países em desenvolvimento tiveram desempenho um pouco mais favorável, com incremento de $12,9 \%$ a.a. nas vendas externas.

Essa diferença na evolução resultou em maior participação dos países em desenvolvimento no comércio mundial ${ }^{29}$. As exportações passaram de $21,2 \%$ do total mundial em 1961, para 26,8\% em 1995. Cresceu também a parcela das importações, de $22,8 \%$ para $28,2 \%$ nesses anos.

No entanto, embora as nações menos desenvolvidas tenham mostrado desempenho favorável no comércio global, perderam espaço nas trocas de produtos agropecuários, produtos que tradicionalmente garantem vantagem comparativa às economias que dispõem de menor disponibilidade relativa de capital. De uma participação de 40,7\% nas exportações mundiais em 1961, passaram a participar com

\footnotetext{
${ }^{29}$ O que, aliás, é desejável se se considera que o comércio externo pode gerar recursos e desenvolvimento tecnológico capazes de reduzir as desigualdades entre as nações.
} 
29,0\% em 1993. Em contrapartida sua parte nas importações cresceu de 19,9\% para $28,9 \%$. Essa, aliás, é a grande transformação das tendências do comércio internacional contemporânea. Países ricos passaram a exportar mais produtos agrícolas enquanto os pobres aumentaram suas importações.

É verdade que as taxas de crescimento das vendas de produtos agrícolas foram bem mais modestas que as do comércio total. Entre 1961 e 1995 as exportações agropecuárias mundiais tiveram expansão de $8,5 \%$ a.a. Isso mais se deveu ao melhor desempenho dos países desenvolvidos que mostraram taxa de crescimento de $9,2 \%$ a.a. contra $7,3 \%$ a.a. nos mais pobres. As importações agropecuárias tiveram comportamento inverso. $\mathrm{O}$ aumento mais acelerado aconteceu nas economias mais pobres $(9,5 \%$ a.a.), enquanto nos países desenvolvidos a taxa de crescimento foi de $7,8 \%$ a.a.

Tabela 1: Taxa Anual de Crescimento do Comércio Internacional, 1961-95 (em porcentagem)

\begin{tabular}{lccc}
\hline & Mundo & $\begin{array}{c}\text { Países em } \\
\text { Desenvolvimento }\end{array}$ & $\begin{array}{c}\text { Países } \\
\text { Desenvolvidos }\end{array}$ \\
\hline Exportação total & 12.0 & 12.9 & 11.8 \\
Importação total & 11.6 & 12.6 & 11.3 \\
Exportação agropecuária & 8.5 & 7.3 & 9.2 \\
Importação agropecuária & 8.2 & 9.5 & 7.8 \\
\hline
\end{tabular}

Fonte de dados básicos: FAO

Isso fez com que os países pobres passassem a importar mais e exportar menos produtos agrícolas. Sua participação nas importações agropecuárias cresceu à taxa de 1,2\% a.a., enquanto as exportações se retraíram em 1,1 \% a.a. Nos países desenvolvidos a taxa de crescimento da participação nas exportações foi de 0,6 \% a.a. contra decréscimo de $0,3 \%$ a.a. nas importações agropecuárias.

$\mathrm{O}$ indicador vantagem relativa na exportação (VRE) agropecuária evidencia o fraco desempenho das nações mais pobres de maneira bem nítida. Em 1961 os países em desenvolvimento apresentavam coeficiente igual a 1,4, contra $-1,4$ dos desenvolvidos ${ }^{30}$. Essa significativa vantagem dos menos desenvolvidos foi se reduzindo ao longo do tempo, chegando ao ponto mínimo em 1980-81. Entre 1982 e 1986 mostrou ligeira recuperação mas voltou a perder espaço até 1992, ano em que o coeficiente $V R E=0,1$, e se manteve nesse nível até 1995 (Figura 1).

\footnotetext{
30 Observar que a fórmula de VRE relaciona a razão entre exportações agropecuárias no país i e nos demais países com a razão entre exportações de outros produtos no país $i$ e nos demais países. Assim, como o mundo foi dividido entre países desenvolvidos e em desenvolvimento, o resultado para os desenvolvidos equivale ao inverso do dos em desenvolvimento. Como se calcula o logaritmo neperiano dos resultados os indicadores apresentm o mesmo número com sinal trocado. O mesmo vale para o indicador competitividade revelada (CR).
} 
O indicador competitividade revelada ( CR), que relaciona todo o comércio e não apenas as exportações, reforça as conclusões acima. De uma situação de nítida superioridade em 1961 (CR = 1,6 contra CR $=-1,6)^{31}$, os países em desenvolvimento foram perdendo competitividade e passaram a mostrar desvantagem entre 1980 e 1981, invertendo o sinal do coeficiente. Em 1982 nenhum desses grupos mostrou superioridade pois $\mathrm{CR}=\mathrm{O}$ para ambos. Depois disso as nações em desenvolvimento revelaram ligeira recuperação, mas, entre 1989 e 1995, a diferença de competitividade pode ser considerada mínima quando comparada aos resultados do início da série (Figura 1 ). Como esse indicador relaciona vantagem na exportação contra vantagem na importação, conclui-se que o comércio agropecuário foi muito desfavorável para os países em desenvolvimento, praticamente ao longo de todo o período analisado.

A análise dos resultados por continente nos permite observar que três deles mostraram nítida tendência de declínio da competitividade agropecuária. São eles

Figura 1: Competitividade Revelada pela Agropecuária dos Países em Desenvolvimento

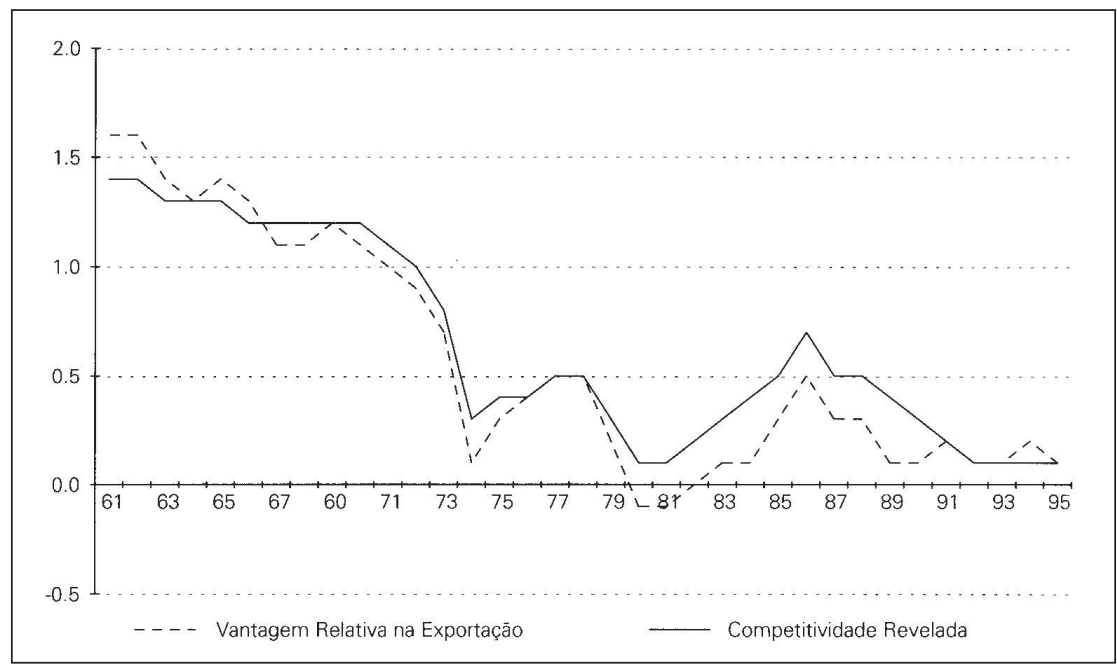

Ásia, África e Oceania. Quanto à Ásia, a menor participação relativa no comércio agropecuário foi largamente compensado por crescimento da participação nastrocas de produtos industriais resultando em crescimento de sua contribuição nas exportações mundiais de 12,5\% em 1961 para 30,5\% em 199732 .

Oceania e África são casos interessantes. No início da década de 1960 ocupavam primeiro e segundo lugares em termos de competitividade da agro-

\footnotetext{
31 Ver nota anterior.

32 A participação da Ásia no comércio agropecuário mundial gira em torno de 15\%. Na década de 1970 sua participação caiu para pouco mais de $12 \%$, mas voltou a ganhar espaço atingindo cerca de $18^{\prime 1} 1 / 4$, entre 1995 e 1997.
} 
pecuária. A Oceania, embora tenha revelado significativa perda de competitividade ao longo de todo o período, ainda pôde sustentar o primeiro lugar e, na década de 1990, o coeficiente CR manteve-se praticamente inalterado. A África, de segundo passou para penúltimo lugar, só perdendo para a Ásia ${ }^{33}$. Observe-se que o indicador $C R$, que já vinha declinando desde o início da série disponível, revelou brusca queda em 1974 e, já no final dos anos 70, passou a negativo. De 1993 em diante, houve certa recuperação, mas o coeficiente permaneceu negativo até 1997 (Figura 2).

O continente americano, no conjunto, revelou ligeiro acréscimo de competitividade entre 1961 e 1984, período em que sustentou, em média, participação pouco superior a $34 \%$ das receitas totais com exportação agropecuária. Daí em diante sua participação declinou, ficando em torno de $27 \%$ entre 1987 e 1997. Observe-se que pelo menos nas Américas do Norte e Central os coeficientes VRE e CR tiveram crescimento até o final da década de 1970, sustentaram por algum tempo essa posição e passaram a perder competitividade de 1985 em diante. $\mathrm{Na}$ América do Sul os resultados são mais instáveis mas revelam piora na competitividade desde 1979 (Figura 2).

Quem ganhou espaço no comércio de produtos agropecuários foi o continente europeu. Em 1961 sua participação nas exportações agropecuárias estava relativamente empatada com as Américas do Norte e Central, em torno de $26 \%$. No entanto, enquanto a Europa cresceu sua parcela à taxa de 1,9\% a.a. até 1992, quando atingiu o pico de 50,6\% nas receitas agropecuárias globais, a norte-americana caiu para cerca de $19,5 \%$. Daí em diante, a posição norte-americana praticamente se manteve, mas, após a conclusão da Rodada Uruguai do GATT, entre 1995 e 1997, a participação européia declinou para 46,2\% nas receitas mundiais com produtos agropecuários.

É interessante observar que o crescimento das exportações européias de produtos agropecuários foi acompanhado por retração das vendas dos demais produtos. Até 1972, quando atingiu o pico de 51,7\% nas receitas das exportações globais, a participação da Europa no comércio mostrava crescimento. Entre 1972 e 1997, sua participação nas divisas com exportação agropecuária cresceu à taxa de 1,7\% a.a. enquanto a dos demais produtos declinava $0,3 \%$ a.a. Em outras palavras, o crescimento das exportações agropecuárias foi acompanhado por retração das vendas dos demais produtos ${ }^{34}$. Isso é o que indica o coeficiente vantagem relativa na exportação. Como os produtos foram divididos em agrícolas e não agrícolas, e aplicamos a expressão algébrica para cálculo da VRE da agropecuária, sua tendência crescente implicou declínio da vantagem relativa na exportação dos demais produtos.

\footnotetext{
33 Que tem larga vantagem relativa na exportação no comércio de produtos industrializados.

${ }^{34}$ Coutinho (1994, p. 96) menciona um estudo de Stoeckel e Breckling, de 1988, mostrando”... que a proteção agrícola na CE contribuiu para a desindustrialização na Europa, diminuindo a produção industrial em 1,2’1/4, e provocando a perda direta de dois a quatro milhões de empregos”.
} 
Figura 2: Competitividade Revelada pela Agropecuária, por Continente

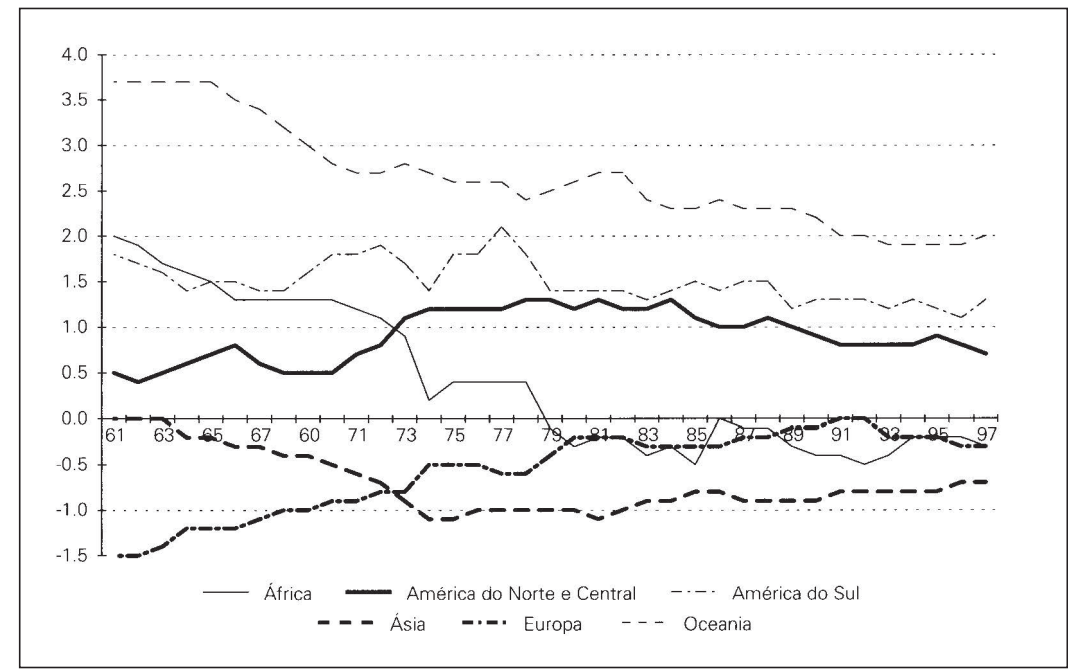

Observe-se que no início da série a agropecuária da Europa apresentava a pior colocação, com VRE $=-1,2$. Ao longo dos anos, no entanto, sistemática e paulatinamente o continente europeu foi reduzindo sua desvantagem nesse mercado. Em 1974 superou a Ásia e nos anos 90 o coeficiente tornou-se positivo, chegando a empatar com a África e Américas do Norte e Central.

O bom desempenho do continente europeu no comércio internacional de produtos agropecuários deveu-se, basicamente, aos países membros da União Européia (UE), onde os coeficientes vantagem relativa na exportação e competitividade revelada mostraram nítida tendência crescente ao longo de praticamente toda a série (figura 3). Esses resultados devem-se ao crescimento da participação nas exportações agropecuárias à taxa de 2,2 \% a.a. ao longo do período 1961-97 enquanto as importações caíram 0,4\% a.a.

Uma evidência adicional do sucesso da UE pode ser obtida quando confrontamos as mudanças de liderança no mercado agropecuário. $\mathrm{Na}$ média do período 1961-63, encontramos, pela ordem, os seguintes países: Estados Unidos (15, 7\% ), Austrália (5,1\%), Holanda (4,0\%), França (3,8\%), Canadá (3,7\%), Brasil (3,3\%), Argentina (3,2\%) e Reino Unido (2,9\%). Observe-se que apenas três deles são europeus, todos pertencentes à UE, e contribuíram com cerca de $11 \%$ das receitas com exportações agrícolas mundiais. Cerca de 30 anos depois mais alguns pertencentes à UE, passaram a figurar entre os primeiros. São eles: Alemanha, Bélgica, Luxemburgo e Itália, elevando a participação do conjunto para $36 \%$ das receit as ${ }^{35}$.

Esses países, acrescidos da China, ganharam posição em detrimento de Ar-

35 A média do período 1993-95 resultou nas seguintes colocações: Estados Unidos (14,1 \%), França $(9,5 \%)$, Holanda $(8,8 \%)$, Alemanha (6,0\%) Bélgica-Luxemburgo (4,3\%), Reino Unido (3,6\%), China $(3,6 \%)$ e Itália $(3,5 \%)$. 
gentina, Austrália, Brasil e Canadá. Os três primeiros revelaram nítida perda de competitividade, sendo que a pior situação é exatamente a brasileira (figura 4 ) ${ }^{36}$. Isso não significa que não mais tenhamos vantagem competitiva nesse mercado, mas que a estamos perdendo aceleradamente. O Canadá foi relativamente mais bem-sucedido. Embora tenha passado de $5^{\circ}$ para $11^{\circ}$ nas exportações agropecuárias, o coeficiente CR revelou certa estabilidade nesses 30 anos, em especial porque, como o conjunto dos países desenvolvidos, pôde reduzir suas importações desses produtos. As demais nações européias não foram bem-sucedidas no comércio agropecuário. Destaque-se a perda de competitividade da Ex-URSS. Esse grupo de países, de uma contribuição de cerca de $4 \%$ das exportações agropecuárias mundiais em 1961, passou para 0,6\% em 1993. O problema é que, nesse caso, o declínio da agricultura não representou crescimento do comércio de outros produtos. Pelo contrário, sua participação nas exportações de produtos não-agrícolas, que chegou a $5 \%$ em 1983, nos anos 90 passou a representar pouco mais de $1 \%$ do total mundial.

A análise por bloco econômico mostra que o NAFTA inicialmente teve certo crescimento na participação no comércio mundial de produtos agrícolas ${ }^{37}$. Os indicadores VRE e CR apresentaram-se relativamente favoráveis, em especial no período 1973-1984. Daí em diante esse bloco perdeu vantagem relativa na exportação mas, como reduziu também sua quota nas importações de commodities agrícolas (à taxa média de 0,6\% a.a.), o indicador competitividade revelada praticamente não mudou.

A competitividade revelada pelo Mercosul no mercado agropecuário foi um pouco melhor que a brasileira mas com idêntica tendência, predominantemente decrescente ao longo de todo o período (Figura 3). Acrescente-se que o bloco perdeu participação no mercado global à taxa média de $0,7 \%$ a.a. entre 1961-93. Como até 1978 teve crescimento de 0,1 \% a.a. da participação nas vendas externas de produtos agrícolas, nessa etapa a queda da vantagem relativa na exportação agropecuária pode ser atribuída ao aumento da vantagem no comércio dos produtos nãoagrícolas, cuja participação cresceu 5,5\% a.a. ${ }^{38}$. A partir desse ano, no entanto, o conjunto dos países da região passou a mostrar tendência de redução da participação nas exportações também desses produtos.

\footnotetext{
36 Se observamos apenas a participação nas exportações constatamos que o Brasil passou de $6^{\circ}$ lugar para $10^{\circ}$. Aparentemente ficamos em melhor situação que Austrália e Argentina, que passaram de $2^{\circ} \mathrm{e}$ $7^{\circ}$ lugares para $9^{\circ}$ e $14^{\circ}$, respectivamente. O problema é que a perda de posição nas vendas foi muito agravada por expansão nas compras de produtos agropecuários. Enquanto a Argentina reduziu suas importações em 1,5\% a.a., em média, período 1961-95, e a Austrália cresceu em 0,2\%., a.a., o acréscimo de importações agropecuárias do Brasil foi de 0,9\% a.a.

${ }^{37}$ NAFTA e MERCOSUL são blocos econômicos que se formaram no final do período estudado e, naturalmente, não tiveram tempo, e talvez nem interesse, de consolidar alguma política agrícola comum.

${ }^{38} \mathrm{O}$ auge da exportação de produtos não-agrícolas se deu entre 1984 e 1985 quando o MERCOSUL contribuiu com $1,1 \%$ das vendas mundiais.
} 
Figura 3: Competitividade Revelada pela Agropecuária, por Bloco

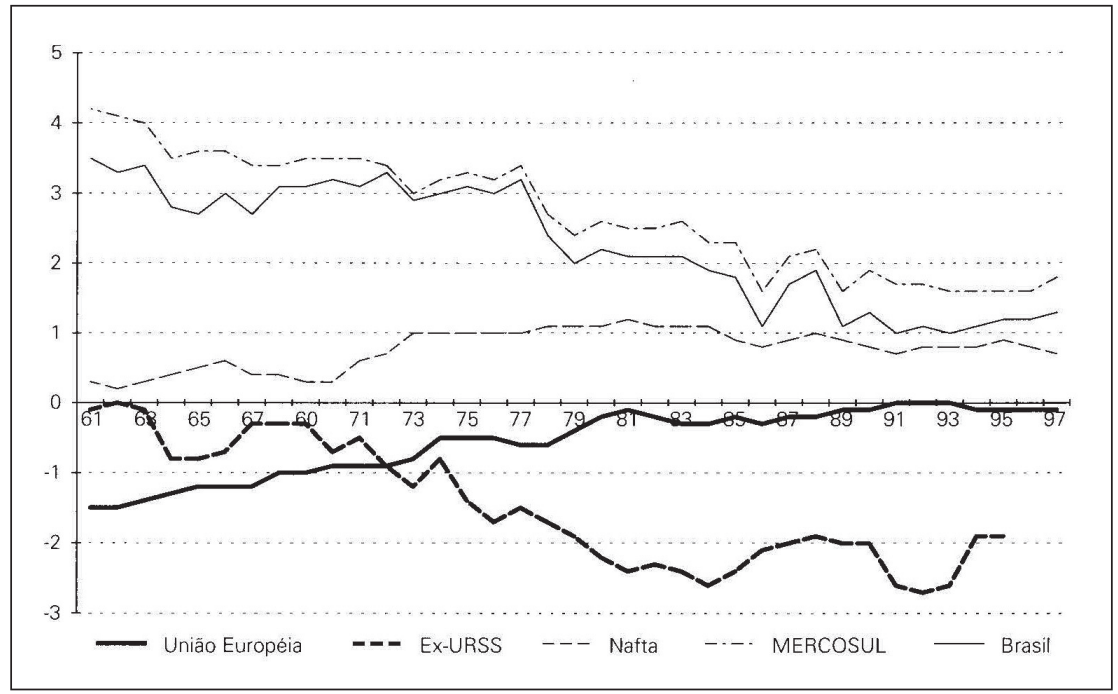

Figura 4: Competitividade Revelada pela Agropecuária de Países Selecionados

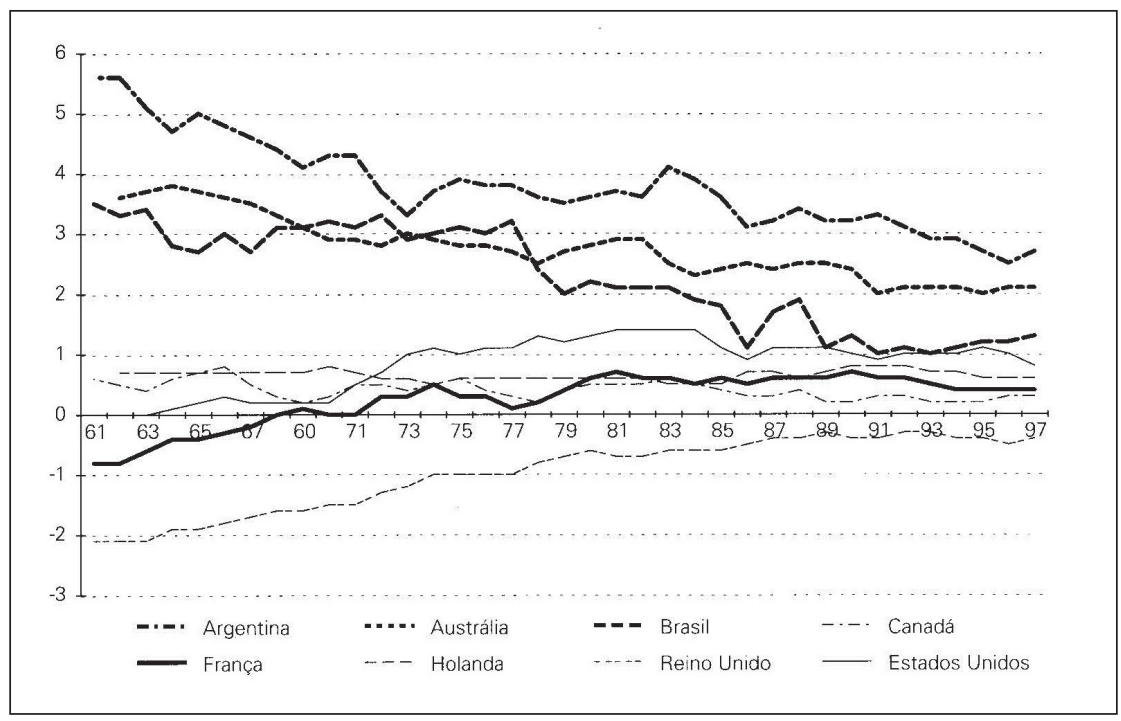

\section{CONSIDERAÇÕES FINAIS}

No século XX, o mundo viveu um período de entusiasmo sem precedentes quanto às possibilidades de benefícios decorrentes da intervenção pública na economia. Nessa etapa o Estado passou a desempenhar um papel estratégico na coordenação da economia capitalista, promovendo o desenvolvimento, corrigindo dis- 
torções do mercado, criando poupança forçada e garantindo distribuição de renda mais igualitária.

As expectativas de sucesso dessa estratégia começaram a arrefecer no final dos anos 60 , mas foi a crise da década seguinte que reforçou os argumentos dos críticos. Nessa conjuntura, o neoliberalismo ganhou espaço e a preocupação dominante passou a ser o Estado mínimo. Os instrumentos para isso seriam o ajuste fiscal, a privatização, a desregulamentação e a liberalização comercial.

Essa lógica, dominante de meados da década de 1970 e que ainda não foi rejeitada de todo, pelo menos para a agricultura não foi levada a sério. Exatamente no auge da adoção do pensamento neoliberal, quando vários países europeus se esforçavam por reproduzir as práticas liberalizantes do governo Thatcher, e os Estados Unidos viviam sob a gestão conservadora do presidente Reagan, o mundo assistiu à escalada do protecionismo agrícola nos dois lados do Atlântico ${ }^{39}$.

A experiência de intervenção do Estado sobre a agricultura é uma prática muito antiga. No início deste século foi utilizada como forma de contornar crises mas, com o tempo e a evolução teórica a respeito, passou a ser considerada recomendável, dado que os riscos e incertezas da atividade consistiam importante falha de mercado, cujos desdobramentos poderiam comprometer o funcionamento de todo o sistema econômico.

Os países mais desenvolvidos, respaldados nessas teorias que justificam o apoio do Estado à agricultura, desenvolveram fortes esquemas de proteção ao setor. Nos Estados Unidos começou com o New Deal. Na Europa ela se consolidou a partir do tratado de Roma em 1957, quando foram definidas as bases da Política Agrícola Comum.

Nos países mais pobres, ao contrário, todo o arcabouço teórico apontava a necessidade de extrair recursos da agricultura para viabilizar a industrialização. E na prática foi o que se fez. O resultado dessa estratégia foi a nítida perda de competitividade no mercado internacional de produtos agrícolas. Os dados analisados nesse trabalho mostram que isso vem acontecendo desde o início da série disponível (1961), a despeito de suas naturais vantagens comparativas nessa atividade.

O conceito de competitividade é aqui interpretado no sentido de indicar variações na participação do país no comércio de determinado produto ${ }^{40}$. Lafay, citado por Obschatko (1992, p. 8), distingue vantagem comparativa de competitividade com base em dois elementos principais:

(a) enquanto competitividade se mede entre dois países para um dado produto, vantagem comparativa se mede entre dois produtos para um dado país;

\footnotetext{
39 O período de maior crescimento do subsídio à exportação à agricultura aconteceu em meados da década de 1980.

${ }^{40}$ Fajnzylber (1988) dá uma interpretação mais abrangente ao conceito. Define competitividade, sob uma perspectiva de médio e longo prazo, como a capacidade de um país sustentar e expandir sua participação no mercado internacional enquanto eleva, simultaneamente, o nível de vida da população. A partir dessa definição, a maneira de atingir melhoria de competitividade é o progresso técnico.
} 
(b) enquanto a competitividade está sujeita à conjuntura macroeconômica, a vantagem comparativa tem um caráter estrutural.

Aproveitando essas distinções concluímos que o caráter estrutural, que dá vantagem comparativa na atividade agrícola aos países mais pobres, com maior disponibilidade de terras e de mão-de-obra, não foi suficiente para vencer os impedimentos colocados pela conjuntura macroeconômica.

Países desenvolvidos, que deveriam ofertar produtos industrializados, foram estimulados pelo governo a competir com os mais pobres no mercado de produtos agrícolas. E venceram. A vitória se deu, inclusive em espaços tradicionalmente ocupados por países tropicais, como café, cacau, açúcar, arroz, banana, algodão, além de alguns de seus derivados, produtos de particular interesse para o Brasil ${ }^{41}$

Até meados dos anos 70 a derrota dos menos desenvolvidos foi compensada por maior competitividade no comércio de produtos industrializados. Depois disso, e particularmente após a crise da dívida externa dos países do Terceiro Mundo, a disputa tornou-se mais acirrada também nesse mercado, inviabilizando novos avanços. O agravante é que passaram a aumentar as importações agrícolas.

Os indicadores vantagem relativa na exportação (VRE) e competitividade revelada (CR), ut_ilizados nesse trabalho, evidenciam essas diferenças de desempenho. Os resultados ressaltam a União Européia como a grande vencedora no comércio agrícola mundial. Seu sucesso foi tão evidente que deu condições ao continente europeu de superar as perdas dos países do leste ${ }^{42}$.

Pela medida VRE, observamos que no início da série a Europa situava-se na pior colocação. No entanto, sistemática e paulatinamente, foi reduzindo sua desvantagem no comércio agropecuário. Em 1974 superou a Ásia e, ao final da série, chegou a empatar com a África e Américas do Norte e Central.

Pela medida CR, o desempenho dos diferentes continentes foi decrescente ao longo do período 1961-95. As exceções ficam com a América do Norte e Europa. É que o indicador relaciona vantagem revelada na exportação e importação. Como em ambos os casos houve declínio relativo das importações agropecuárias, o resultado mostrou-se favorável para essas regiões. A diferença é que, enquanto a Europa sustentou a tendência de crescimento praticamente ao longo de toda a série, em meados da década de 1980, a América do Norte sofreu certa perda de competitividade. A razão básica do avanço europeu sobre os mercados de outros países foi,

41 Pela comparação das médias dos triénios 1961-63 e 1993-95, observamos que a participação dos países desenvolvidos nas receitas de exportação mundial de café em grão cresceu de $0,16^{1} 1 / 4$, para 1,29\%, enquanto reduziu de $13,5 \%$ para $7,9 \%$, nos países em desenvolvimento. O conjunto café, cacau e chá passou de $1,7 \%$ para $4,0 \%$ nos países mais ricos contra redução de $23,10 \%$ para $14,38 \%$ nos mais pobres. O curioso é que o Brasil perdeu espaço, mesmo em produtos em que o aumento de produtividade da terra mostrou-se significativamente superior ao do resto do mundo. Carvalho (1996) mostra que isso aconteceu, particularmente no período 1978-93, para as culturas de algodão, arroz, cana-de-açúcar, cereais em geral, milho e soja.

${ }^{42}$ Lembrando que o sucesso está sendo avaliado em termos da evolução da participação no mercado. Naturalmente esta não é urna medida de bem-estar. 
sem dúvida, a agressiva Política Agrícola Comum. Durante muito tempo a União Européia recebeu pressões de outros países exportadores, em especial dos Estados Unidos, no sentido de reduzir seu protecionismo, mas sem sucesso. A idéia era levar o problema ao âmbito do GATT, mas os europeus resistiam em aceitar a inclusão desse tema nas negociações. Fagundes (1994) menciona que a UE só aceitou negociar quando passou a despender $60 \%$ do seu orçamento com programas agrícolas.

A relevância da PAC fica ainda mais evidente quando se observa que, na média do período 1961-63, dentre os oito maiores exportadores de produtos agrícolas, três pertenciam à UE. Cerca de trinta anos depois, dos oito líderes mundiais, seis pertencem à UE. São eles, pela ordem, França, Holanda, Alemanha, BélgicaLuxemburgo, Reino Unido e Itália, que juntos absorveram 36\% das receitas com exportações agropecuárias.

A maior vantagem dos membros da UE deve-se ao fato de colocarem-se entre os que mais expandiram a exportação agropecuária enquanto reduziram sua quota nas importações. De contribuição de $22 \%$ das receitas mundiais com exportações em 1961, passaram a representar $41 \%$ em 1997, passando por um pico de $48 \%$ em 1992, enquanto os gastos com importações agropecuárias caíram de 49\% para $41 \%$ entre os extremos da série.

Como ambos os indicadores mostram que esse conjunto de países partiu da pior colocação em termos de competitividade, tudo leva a crer que a reversão desse quadro só foi possível devido ao esforço conjunto do bloco. Isso nos induz a concluir que a política agrícola européia provocou grandes desvios de comércio e contribuiu para reduzir a eficiência na alocação de recursos mundiais.

Acrescente-se que os resultados para o período 1995-97 talvez representem uma evidência adicional da influência da política agrícola sobre o desempenho no comércio internacional. Como se sabe, a Rodada Uruguai do GATT, concluída em 1994, estabeleceu um cronograma de redução dos subsídios agrícolas a partir do ano seguinte. O curioso é que, nesse período, os resultados mostram certa mudança de tendência, desfavorável à União Européia e Estados Unidos.

Naturalmente a metodologia empregada neste trabalho não possibilita identificar a razão das mudanças nas vantagens competitivas. Serve, no entanto, de indicação do desempenho. Se, como acreditamos e os resultados parecem confirmar, as mudanças do desempenho realmente são condicionadas pela política agrícola, a próxima negociação multilateral, no âmbito da OMC, prevista para o ano 2000, é uma boa oportunidade para o Brasil pressionar por ainda maiores reduções no protecionismo agrícola mundial.

\section{REFERÊNCIAS BIBLIOGRÁFICAS}

ABREU, Marcelo P. e LOYO, Eduardo. "A estrutura do comércio agrícola mundial: fundamentos dos interesses liberais e protecionistas”. In: FAGUNDES, Maria H. Políticas agrícolas e o comércio mundial. Brasília, IPEA, 1994. 
BALASSA, Bela.'Trade liberalization and 'revealed' comparative advantage".The Manchester School of Economic and Social Studies, 1965.

BANCO MUNDIAL. Relatório sobre o desenvolvimento mundial. Washington, BIRD, 1997. BOCKE R,TilmanC.”Apolíticaagrícolacomumdacomunidadeeconômicaeuropéia”. ln: FAGUNDES, Maria H. Politicas agrícolas e o comércio mundial. Brasília, IPEA, 1994. pp. 89-127.

BRESSER-PEREIRA, Luiz C. Crise econômica e reforma do Estado no Brasil. São Paulo, Editora 34, 1996.

BROWN, Lester R. "Revolução agrícola na Ásia”. ln: ARAÚJO e SCHUH (org.).Desenvolvimento da Agricultura: estudos de casos. São Paulo, Pioneira, 1983, pp. 129-51.

CARVALHO, M. A. e SILVA, C. R. "Políticas agrícolas dos países desenvolvidos”.Informações Econômicas, São Paulo, vol. 25 (supl. 1), pp. 1-112, 1995.

CARVALHO, Maria A. Estabilização dos preços agrícolas no Brasil: a política de garantia de preços mínimos. São Paulo, IEA, 1994 (Coleção Estudos Agrícolas, 1).

"A competitividade da agricultura brasileira". Pesquisa \& Debate, São Paulo, vol. 7, n 2(9), 1996. pp. 51-74.

CASTRO, Ana C. et al. Evolução recente e situação atual da agricultura brasileira: síntese das transfor mações. Brasília, BINAGRI, 1979 (Estudos sobre o Desenvolvimento Agrícola nº7).

COUTINHO, Paulo C. O impacto de políticas de suporte à agricultura sobre a economia brasileira: uma proposta de quantificação. Brasília, IPEA, 1994 (Estudos de Política Agrícola no 29).

DELGADO, Guilherme C. Uma metodologia para determinação dos preços mínimos. Brasília, CFP, 1978 (Coleção Análise e Pesquisa, 3).

FAGUNDES, Maria H. Políticas agrícolas e o comércio mundial. Brasília, IPEA, 1994. (Estudos de Política Agrícola n ${ }^{\circ} 28$ ).

FAJNZYLBER, Fernando. "Competitividad internacional: evolucion y lecciones". Revista de la CEPA L. n 36, Santiago de Chile, Deciembre 1988, pp. 7-24.

FEI, John C. H. e RANIS, Gustav.” Agrarianismo, dualismo e desenvolvimento econômico”. ln: ARAÚJO e SCHUH (org.). Desenvolvimento da Agricultura: estudos de casos. São Paulo, Pioneira, 1983, pp.101-36

FRISCHTAK, Cláudio R. “O novo papel do Estado — políticas regulatórias e reformas regulatória sem países em processo de industrialização”. Revista Brasileira de Comércio Exterior, Rio de Janeiro, n 35 , abr.-jun./1993, pp. 14-25.

FURTADO, Celso. Formação econômica do Brasil. São Paulo, Companhia Editora Nacional, 1969.

JOHNSON, D. Gale. Forward prices for agriculture. Chicago, University of Chicago, 1947. 259 p.

"Perspectivas da oferta mundial de alimentos". In: CONTADOR, Cláudio R. Tecnologia e desenvolvimento agrícola. Rio de Janeiro, IPEA/INPES, 1975, pp.267-83.

JOHNSTON, Bruce F. \& MELLOR, John W. “The role of agriculture in economic development”. The American Economic Review, Wisconsin, 51(4):566-93m, sep. 1961.

JORGENSON, Dale W. Teste de teorias alternativas de desenvolvimento em economia dualista. ln: ARAÚJO e SCHUH (org.). Desenvolvimento da Agricultura: estudos de casos. São Paulo, Pionei ra, 1983, pp. 137-52.

LEWIS, Arthur W. "O desenvolvimento econômico com oferta ilimitada de mão-de-obra”. ln: AGARWALA, A. N. e SINGH, S. P. A economia do subdesenvolvimento. Rio de Janeiro, Forense, 1969, pp. 406-56.

KETTL, Donald, F. “A revolução global: reforma da administração do setor público”. ln: BRESSER-PEREIRA, Luiz C. e SPINK, Peter (org.) Reforma do Estado e administração pública gerencial. Rio de Janeiro, Fundação Getúlio Vargas, 1998, pp. 75-121.

MENDONÇA DE BARROS, José R. Política e desenvolvimento agrícola no Brasil. São Paulo, IPE/USP, 1982 (Trabalho para discussão interna,16/82).

NAÇÕES UNIDAS, FAO. National agricultura / price stabilization and support policies: guiding principies recommended by FAO. Roma, FAO, 1961. 
OBSCHATKO, Edith S. Desempeno y competitividadde $i$ compleio agroindustrial argentino.Buenos Aires, Secretaria de Programación Economica/IICA,1992.

O'CONNOR, James. The fiscal crisis of the State. New York, St. Martin Press, 1973.

PRZEWORSKI, Adam. "Sobre o desenho do Estado: uma perspectiva agent x principal”. ln: BRESSER-PEREIRA, Luiz C. e SPINK, Peter (org.) Reforma do Estado e administração pública gerencial. Rio de Janeiro, Fundação Getúlio Vargas, 1998, pp. 39-74.

SANDERSON, Fred H. Agricultural protectionism in the industrialized world. Washington, D. C. Resources for the Future, 1990.

SONKA, Steven T. e PATRICK, George F. "Risk management and decision making in agricultura! fir$\mathrm{ms}$ ”. In: BARRY, Peter J. Risk management in agriculture. Ames, Iowa State University, 1984, pp. 95-115.

STIGLER, George. The citizen and the State. Essays on regulation. Chicago, University of Chicago Press, 1975.

STOECKEL, Andrew B; VINCENT, David; CUTHBERTSON, Sand (ed.) Macroeconomic consequences of farm support policies. London, Duke Press Policies Studies,1989.

TANZI, Vito; SCHUKNECHT, Ludger. "Reforma do governo nos países industrializados". Rio de Ja neiro, Finanças \& Desenvolvimento, 1996.

THORSTENSEN, Vera. Comunidade Européia: líder do comércio internacional. São Paulo, Aduanei ras, 1993.

TYERS R. e ANDERSON, K. Liberalizing OECD agricultura! policies in the Uruguay Round: effects on trade and welfare. Journal of Agricultural Economics, London, 39(2):197-216, May 1988.

VEIGA, Alberto. The impact of trade policy on Brazilian Agriculture, 194 7-1967. Purdue University, 1974 (doctoral thesis).

VOLLRATH, T. L. "Competitiveness and protection in world agriculture". Agriculture Information Bulletin. n” 567, USDA, jul. 1989.

YOUNG, Peter. "A transferência da experiência de privatização britânica para outros países". ln: ZINI, Álvaro A. (org.) O mercado e o Estado no desenvolvimento econômico nos anos 90. Brasília, IPEA, 1993.

WEBB, A. B. ct ai. Estimates of producer and consumer subsidy equivalents: government intervention in agriculture, 1982-87. Washington, 1990 (Statistical Bulletin,803).

WOL; Charles, Jr. "A theory of non market failure: frame work for implementation analysis". journal of Law and Economics, 22:107-39, 1979. 